\title{
Human Integrity as Modern Socio-Philosophical Problem
}

\author{
Irina Ponizovkina ${ }^{1, *}$ Elena Agibalova ${ }^{2, a}$
}

\author{
${ }^{1}$ Department of History and Philosophy, Plekhanov Russian University of Economics, Moscow 117997, Russia \\ ${ }^{2}$ Department of Foreign Languages, Plekhanov Russian University of Economics, Moscow 117997, Russia \\ ${ }^{\mathrm{a} E-m a i l: ~ e l e n a g i b @ r a m b l e r . r u ~}$ \\ *Corresponding author.E-mail: irina-ponizovkin@mail.ru
}

\begin{abstract}
The article addresses the subject of human integrity being one of the central problems of philosophy. In the modern era of postmodernity, informatization and digitalization, the problem of human integrity fragmented personality, the mosaic structure of consciousness, the atomic nature of existence, etc. - are especially relevant. The article analyzes the cases and different approaches to the study of this problem in the history of philosophy and modern practice. The author identifies the problems of the unity of the natural and social in a person, the fulfillment of complete social existence of the individual " $I$ " through the relationship with "You", the internal unity of personality through the consistency of actions, words and practices.
\end{abstract}

\section{Keywords: philosophical anthropology, human, personal integrity, human essence}

\section{INTRODUCTION}

The problem of human integrity can be considered, in one form or another, traditional for philosophy. Throughout history, this topic was understood and covered by thinkers in different ways, however, always remaining significant for them since studying the problem of human integrity helps reveal the essence and the purpose of human existence, analyze their activity and solve many social and anthropological problems.

Since ancient times, philosophers have been interested in this subject and have seen the harmony of human existence in his/her unity. At the same time, they also mentioned the duality and versatility of a human being.

\section{HISTORICAL BACKGROUND}

As a rule, humans in ancient philosophy were considered through the unity or opposition of their main modes - soul and body. In the eastern religious and philosophical tradition, these modes were not opposed, but were naturally interconnected and defined each other (Buddhism, Taoism, etc.). The existential essence of a human is determined by the laws of the universe, a human being an organic part of it. Western ancient philosophy opposed soul and body and proposed a thesis on the existential inferiority of a person. This human dualism was well described by Plato. However, he thought that the unity of human existence can be achieved through the primacy of soul, returning a human to cosmic harmony. In the Middle Ages, the modes of the sinful body and individual soul, reflecting the inscrutability of the disposition of providence, were joined by the third hypostasis - spirit as the ability to become part of the divine, the desire to comprehend the general laws of Being [1]. In Renaissance humanism, this opposition between soul and body was overcome, and a human, existentially being a creative person, was perceived as an employee of God.

During further development of philosophical anthropology, new aspects of human existence and manifestations of their essence were revealed, together with new problems of human integrity. Kant represented a person as a resident of two different worlds - the natural and the Divine world, where the transcendental subject embodies the creative possibilities of its Mind. Hegel introduced the concept of alienation, which was further developed in anthropology (for example, in Marxism), on the role of human consciousness as a manifestation of absolute mind and a unifying force.

In the second half of 19-20 centuries anthropology saw a turn in understanding of the human essence, new aspects in human integrity associated with the crisis of existence, ontological unrootedness and incompleteness of a human were identified.

In Russian religious philosophy of this period, this problem is studied within the concept of unitotality and collegiality, which considers love as a great unifying 
force. The great Russian philosopher V.S. Solovyov emphasized the inexhaustibility of a human personality as an expression of the universal, and, thus, the unlimited nature of self-improvement activities. In the Soviet philosophy, the concept of a holistic, comprehensively developed personality was widespread. A holistic, harmoniously developed personality must combine spiritual wealth, moral purity, and physical perfection.

The $21 \mathrm{st}$ century marked by the information revolution and postmodernity saw the identification of approaches to the existing problems as well as the emergence of new ones regarding human integrity and existence - problems of the fragmentation of human consciousness, death of the subject, etc.

\section{HUMAN INTEGRITY AS THE UNITY OF NATURAL AND SOCIAL}

A person is complicated and inexhaustible, being rooted in various layers of the Universe. Therefore, the problem of human integrity has many aspects. It can also be considered at different levels of human existence. This defines various approaches to the problem of human integrity and its classification. At different stages of philosophical anthropology development, thinkers discovered more and more new aspects of this central theme of human existence. Let us review the main modern anthropological approaches to studying integrity. Probably, the classic, most common one is an approach to understanding the integrity of a person based on the unity of bodily and spiritual life, the correlation of natural and social-spiritual in a person. Which is more important in a person - the body or his/her social essence? And is it possible to actually distinguish the main component? So far, people have not given a definite answer, although the solution of this problem is important for the development of society, including pedagogy and education. Judging by the modern global education strategy, which trains rolemodel consumers, one might think that humanity has already received an answer that sheds light on the nature of a human. Many thinkers (especially social Darwinists), researchers in the natural sciences, doctors not only do not see the impassable abyss between human and animals, but also consider a human an animal living according to the same natural laws. One can one not recall the ancient Roman proverb of Plautus (Asinaria, 3rd century BC), used by the philosopher Hobbes (De Cive, 1651): "man is a wolf to man." Or a person is perceived as a biologically inferior creature, making up for their natural inferiority with sociocultural mechanisms. The current level of moral decline of mankind makes this view of human nature very popular. Indeed, humans have inherited a lot from nature, which unites them with the animal world obeying the laws of nature, biological needs, instincts, "will to live", etc. However, there is something in human nature that once and for all separates them from the animal world and brings us closer to solving the problem of the unity of natural and social in human. Human is the only biological creature whose generic features do not manifest themselves with necessity, without certain social conditions. This is confirmed by the fate of feral people, the so-called "Mowgli". Growing up since early childhood in the natural environment, among animals, but far from the human community, these living creatures although having the necessary biological tools to become humans (arm structure, human brain, larynx, etc.), never became ones. Despite all the combined efforts of psychologists, biologists, sociologists, doctors and other experts, they never acquired abstract thinking, speech and cultural skills necessary for a human, could not assimilate into a human society, remaining animals, in fact. This convinces us that without social environment and human mutual communication, the generic features of a person are not developed. This shows human original uniqueness and natural-social unity, expressed in the interdependence of these system components.

\section{WHOLENESS OF SOCIAL EXISTENCE OF "I" THROUGH "YOU"}

We can also highlight the integrity of the external human existence, to some extent related to the information mentioned above. A person will not just fail to develop without a human community, but he or she also needs it for proper existence and selfrealization, without which it is impossible to imagine the integrity of a person as a social being. The comprehension and manifestation of one's multilateral essence can be achieved by a person only in society. This was metaphorically expressed by Plato in his dialogue The Symposium [2], where he tells us how Zeus cut people in half, punishing them for pride by depriving them of integrity, eternal suffering and desire to find their other half. This other half is the second part of the soul, necessary for a feeling of joy and wholeness of being, mutual understanding, unity and love, which Aristophanes explains as "a thirst for integrity and the desire for it."

Despite the metaphorical nature of Plato's approach, he expressed the essence of the problem, which was further developed. For example, L. Feuerbach [3] [4] [5], considering a person through the prism of naturalistic materialism, nevertheless takes them beyond the limits of individualized natural being. The philosopher makes Love in the broadest sense, when there is no "I" without "You", his "religion". Through the inextricable connection of human with human, through mutual openness, understanding of the other (different) a person cognizes him- or herself, being reflected in the other. A person completes him-or- 
herself, overcoming existential inferiority and alienation, finds wholeness and harmony of inner being.

One cannot but recall V.S. Solovyov [6] with his idea of Unitotality, which updated the anthropological aspect through the concepts of Love and Collegiality. Love for the Russian thinker means overcoming any separateness, individualism and selfishness; it is the basis of the endless process of self-improvement and building oneself to the wholeness of the universal. A person in a multitude of interconnections and interactions is looking for a unique social niche that would become a fortress for them protecting their inner life, and for society - a necessary and irreplaceable part of the harmony of the social "mosaic".

\section{INTERNAL UNITY OF PERSONALITY}

We studied above the external aspects of human integrity, their integration into the world around us, affecting the wholeness of human existence. But the inner manifestations of this phenomenon can also be observed. Thus, today the problem of internal unity or authenticity of personality - the absence of a split character, the consistency of actions, words and activities, the ability to remain oneself in any situation generates interest. Such manifestations of the internal unity of personality depend greatly on the level of selfconsciousness development (self-knowledge, selfimage, self-control, etc.), affecting essential actualization and harmonious existentiality of a person. A person gains principles, which cement his or her personality, being guided by them in life and activity rather than by the current situation.

Today, management theory pays a lot of attention to the problems of personality integrity of a manager and leader, bringing this philosophical problem to the practical field. Researcher V.E. Selezneva specifies the following basic qualities of leaders' integrity [7]:

- Authenticity, i.e. The ability to go beyond social roles, openly displaying genuine, inherent only to a given personality, thoughts, emotions and behavior and assuming full responsibility for this;

- Developed self-awareness, capable of going beyond oneself, overcoming internal and external contradictions on the basis of universal values;

- Spirituality as a quality that allows us to comprehend, experience and adopt the highest ideals and values of a person and society and transform activity into behavior, activities into actions;

- Social maturity, the ability to make independent decisions and bear personal responsibility for them, to accept, comprehend and evaluate the contradictions of life; resolve them independently and productively in accordance with the most common goals, moral ideals;

- Conscience as a body, providing the opportunity to listen to one's own inner voice and allowing one to overcome the contradictions between internal debt and external circumstances, between what has been said and done, between one's own and others' interests, etc.;

- The balance between intellectual and creative potential, where the first one contributes to the stabilization and sustainability of the existence of a personality in a rapidly changing world, and the second one gives a person the opportunity for self-development.

The significance of the integrity of a person for the functioning of a human is associated with trust in them from others, with their reputation, the harmony of social existence and self-realization.

\section{CONCLUSION}

The problem of human integrity has a long tradition of philosophical analysis. The famous Russian philosopher N.A. Berdyaev wrote, "Personality is integrity and unity, possessing unconditional and eternal value" [8]. According to him, a personality is eternal tension and search. A personality is created, developed, enriched and becomes oneself, gaining integrity. We agree with the fundamental conclusion of the Russian philosopher P. S. Gurevich that to be integral means to gain wholeness of existence, to unlock human potential [9].

The solution to the problem of human integrity has a concrete historical character. In the modern era of postmodernity, informatization, and digitalization, this problem of integrity - the fragmented personality, the mosaic structure of consciousness, the atomic nature of existence, etc. is especially relevant and requires further detailed philosophical study. The solution to these problems defines not only the development vector of human civilization, its further progress, but also the possibility of human existence at all.

\section{References}

[1] Olga V. Chistyakova, "Religious anthropology of Eastern (Greek-Byzantine) Patristics". European Journal of Science and Theology. December 2019. Vol. 15, № 6. Pp. 145-155.

[2] I. Kant, "The Critique of Pure Reason" / I. Kant. - Minsk. Literatura, 1998.

[3] L. Feuerbach, "Principles of Philosophy of the Future "// L. Feuerbach, Selected philosophical works: in 2 vols, vol. 1. Moscow: Izdatelstvo politicheskoy literatury, 1955, pp. 134 204. 
[4] L. Feuerbach, "Against the dualism of body and soul, flesh and spirit" // L. Feuerbach, Selected philosophical works: in 2 vols, vol. 1. Moscow: Izdatelstvo politicheskoy literatury, 1955, pp. 211-238.

[5] L. Feuerbach, "The essence of Christianity" // L. Feuerbach, Selected philosophical works: in 2 vols, vol. 2. Moscow: Izdatelstvo politicheskoy literatury, 1955, pp. 7-405.

[6] V.S. Solovyov, Collected works in 2 vols., vol. 1, Moscow, 1998.

[7] V.E. Selezneva, "Leadership. The integrity of personality as one of the main guidelines for the development of a leader" // Available:

https://studme.org/34169/menedzhment/tselostnost_lichnosti_ka k_odin_osnovnyh_orientirov_razvitiya_lidera

[8] N.A. Berdyaev, "The Destiny of Man", Moscow: Respublika, 1993, p.62.

[9] P.S. Gurevich, "Psychoanalysis of personality", Moscow: Institut Obshchegumanitarnykh Issledovaniy, research, 2011. 